\title{
International marketing in an enlarged European Union: Some insights into cultural heterogeneity in Central Europe*
}

\author{
Heather Skinner, Krzysztof Kubacki, Gloria Moss, David Chelly**
}

We inhabit a global village in which international marketers are encouraged to think and act with both global and local interests in mind. The enlargement of the European Union (EU) in January 2007 has created a 27 member state EU with a population of nearly half a billion. The purpose of this article is therefore to examine the nature of these differences in so far as they impact on the segmentation decisions made by international marketers. This article examines the literature on culture, identity, and self-concept and presents empirical results showing the diversity of these concepts within three countries that are now full EU members - the Czech Republic, Hungary and Poland.

Wir bewohnen ein globales Dorf, in dem internationale Verkäufer dazu ermuntert werden in globalem und lokalem Interesse zu denken und zu handeln. Die Erweiterung der Europäischen Union im Januar 2007 hat einen Wirtschaftsraum mit 27 Mitgliedstaaten und einer Bevölkerung von fast einer halben Milliarde geschaffen. Die Absicht dieses Artikels ist es deshalb, die Natur dieser Unterschiede zu untersuchen, insofern sie auf die Marktsegmentations-Entscheidungen der Verkaufs-Experten einwirken. Der Artikel untersucht die Literatur bezüglich Kultur, Identität und Selbstkonzept und präsentiert empirische Ergebnisse, die die Ungleichheit dieser Konzepte innerhalb von drei Ländern - Tschechien, Ungarn und Polen - aufzeigen.

Key words: International Marketing, segmentation, EU enlargement, identity

Manuscript received: 25.10.06, accepted: 02.05 .08 (1 revision)

** Heather Skinner, Senior Lecturer, University of Glamorgen. Main research areas: National identity through nation bands.

Krzysztof Kubacki, Lecturer, School of Economic and Management, University of Keele. Main research areas: Main research areas: Relationship between maketing and music and cross - nation comparisons between consumers in the EU. Corresponding address: k.kubacki@mngt.keele.ac.uk.

Gloria Moss, Research Fellow, University of Wales. Main research areas: Human resource and segmentation marketing.

David Chelly, Prof., Ecole Superieure de Gestion. Main research areas: Business with Central and Easter Europe. 


\section{Introduction}

Initial Eastward enlargement of the European Union (EU) in May 2004 created a domestic European market of over 450 million consumers in 25 member states, with further enlargement in January 2007 taking membership of the EU to 27 countries with a population of almost half a billion. Accession negotiations with Croatia and Turkey started in 2005, and, although an official candidate, a start date for negotiations with Macedonia has not yet been set. While authors such as Paliwoda and Marinova (2007:234) identify the EU as "the largest single market in the world and the largest entity in world trade", making it a very significant area for academic study, much of the recent literature has focused specifically on the challenge of integrating a diverse EU that now includes member states from the former Eastern Bloc. In their editorial, Paliwoda and Marinova (2007:239) note that "EU marketing studies have addressed issues in specific country contexts, industries, cultures and geographic areas rather than being able to tackle pan-European marketing issues". They also identify that some of the challenges facing those aiming to segment enlarged EU markets are rooted within the debate on convergence and divergence.

Globalisation has given rise to claims concerning the contracting role of the nation-state (Steger 1998), and the dilution of national identity (Williams 1999), "mirroring the insidious movement of power in any economic union, from the periphery to the centre" (Skinner/Croft 2004:8). Many authors recognise that in a globalised world convergence is evident that will lead to cultural similarities overshadowing cultural differences (Pugh/Hickson 2002; Zielonka/Mair 2002). Indeed Fuchs and Klingemann (2002) explore the belief that a democratically legitimate "European demos" can only be based upon a collective identity, although are concerned that, given the cultural heterogeneity within and between member states, this may not be achievable. Moreover, Aveline (2006) asserts that it is the creation of supra-national entities such as the European Union that moves the concept of the nation state "beyond the national framework" (p336) and towards a post-national order where the classic parameters of the nation are rethought, unbounded by geography and national politics in the face of globalisation, and where nationhood is superseded by a higher notion of citizenship. When considering the post-national argument that nationhood will become less important when cultures converge in a globalised world, it is also important to recognise the opposing argument proposing that nationhood will become more important to individuals in such circumstances.

"In a world where the mass media creates global homogeneity yet where in this global village people and populations are increasingly differentiated", McRobbie (1994:40) believes that a "further imperative is an examination of what we mean by identity, and what value this concept has for cultural analysis". However, marketing has been criticised for its reliance on "outmoded frameworks", this being seen as one of the obstacles to marketing's full 
engagement in the "strategy dialogue" (Bean/Robinson 2002:204). One such framework, often used when examining issues surrounding the culture of markets, was proposed by Hofstede in 1980. Contemporary criticisms of Hofstede's work are of its origins in outdated anthropological concepts, that the study investigated cultural values of a company not a 'market', did not take into account employees as "consumers, negotiators or market intermediaries", and was conducted in the 1960s, prior to globalisation and the technologies that fuel the knowledge economy (Holden 2004). Holden's criticisms of Hofstede's continuing relevance go so far as to blame marketers' "uncritical acceptance of his models and characterisations" for having an "intellectually numbing effect on the treatment of culture and international marketing", and he proposes that blind dependence on Hofstede be abandoned (Holden 2004:565). Instead, Holden (2004), believing that "culture is a dead resource until its value and utility are recognized as knowledge" (568), proposes new perspectives on culture that seek to identify not cultural aggregates based upon geographic national borders, but rather "clusters of affinity" based upon culture that may cross national borders, a view shared by, amongst others, Van der Merwe and L'Huillier (1989) and Mercado, Welford and Prescott (2001). However, we propose that there is a high degree of diversity between EU accession nations, and that they do not form one Central or Eastern European "cluster of affinity" within an enlarged EU. Although there is evidence to suggest that international marketers may be tempted to treat these newly acceded members as a homogeneous target market segment, authors such as Manrai et al. (2001:271) identify that heterogeneity can be found across "factors such as culture, history, language, and the duration and intensity of Communism and its economic doctrine" and that "there are differences in the degree of industrial development $\ldots$ and in the approach toward the transition to a market economy ... leading to a three-speed Eastern Europe". As Rojsek (2002:509) noted, "multinational companies planning to enter the Eastern European market frequently assume that this region is culturally and economically undifferentiated". However, while her study found differentiation between Slovenian and other Eastern European consumers, Rosjek herself distinguishes only between Western Europe and Eastern Europe in which she categorises the Czech Republic, Hungary, Slovakia, Slovenia and Poland. Yet there are even further distinctions to be made between nations referred to by Manrai et al. (2001:274) as "more Westernized", such as the Czech Republic, Hungary, Poland and Slovakia who consider their location to be in Central Europe, as opposed to being located in Eastern Europe along with less Westernized nations such as Bulgaria, Russia and the Ukraine (Jonscher/Summefield 1994).

The purpose of this article is therefore to examine the nature of these differences insofar as they impact on the segmentation decisions made by international marketers. It does so by examining the literature on culture, identity, and selfconcept and presents empirical results showing the diversity of these concepts 
within three of the former communist countries that are now full EU members the Czech Republic, Hungary and Poland, and thus this article uses not Hofstede's cultural framework, but rather examines the literature on culture, identity, and self-concept from a range of academic disciplines in order to gain insight into similarities and differences in international markets that may contribute to marketing knowledge. Our findings into these distinct areas of difference and similarity are based upon a survey of 841 nationals in three accession member states of the European Union: Poland $(n=383)$, Hungary $(n=240)$ and the Czech Republic $(n=218)$. The article therefore offers a new framework for researching culture based upon a range of disciplines. The knowledge that may be applied from these insights may aid twenty-first century international marketers who may otherwise be tempted to treat lesser known or relatively new national markets as homogeneous target market segments if reliant upon outmoded frameworks to inform them.

\section{The European Union and the Nation -State}

The European Economic Community (EEC) was founded by the Treaty of Rome in 1957 with six member nations: Belgium, France, Italy, Luxembourg, the Netherlands and West Germany. These nations were joined, in 1973, by Denmark, Ireland and the UK. Greece joined the EEC in 1981, with Portugal and Spain joining in 1986. The EEC was the forerunner of the entity we now know as the European Union (EU) The EU, formed by the 1993 Maastricht Treaty, extended the scope of the EEC, and established co-operation in common foreign and security policy and justice and home affairs, also establishing the groundwork for a single European currency. At the time of its creation the EU comprised 12 member states. Austria, Finland and Sweden joined the EU in 1995 shortly after its creation, and the 15 member state EU remained stable in composition for almost 10 years.

The initial eastward enlargement of the single European market in May 2004 and further enlargement in January 2007 has brought the issue of a single European identity into sharp focus. Mayer and Palmowski (2004) believe that much more scholarly attention needs to be paid to the question of European identities, and they note that such studies should range across historical, cultural, constitutional, legal and institutional perspectives. From its Latin etymology 'cultura', "in the broadest sense, one might define culture as 'the result of human action"” (Warner/Joynt 2002:3)." Although Mayer and Palmowski accept the difficulty in attempting to identify a single cultural identity for Europe, they also identify the impact of European identity on cultural identities, and believe that "a distinctive, 'value-added' European identity is closely related to the persistence of national identities ... it is the nation-state that continues ... to be the primary frame of reference for the community" (2004:590). This may be 
unsurprising considering that "Europe has been described as the birthplace of the concept of the nation-state" (Burgoyne/Routh 1999:111).

Cobban (1969) has traced the growth of the nation state to the middle ages, a time when states were "political entities and there was no belief in any necessary connection between cultural and political ties". However, he found that there are opposing views as to what constitutes a nation. One perspective favours definitions based on political unity irrespective of nationality. Cobban (1969) gives the example of the Hungarian Law of Nationalities of 1868 stating that: "all citizens of Hungary ... form a single nation - the indivisible unitary Magyar nation - to which all citizens of the country, irrespective of nationality, belong" (p36). The opposing conception of the nation is that most favoured by, among others, Herder, the founder of German nationalist thought, who, according to Cobban was "almost exclusively concerned with the idea of the nation as a cultural entity". The definition of a nation to include a commonality of a sense of community is shared by Ernest Gellner, an important scholar of nationalism, who takes the view that "two men are of the same nation if and only if they share the same culture, where culture in turn means a system of ideas and signs and associations and ways of behaving and communicating" (Gellner 1983:6). Cobban notes that "the modern Western European conception of the nation has largely been a product of the fusion of these two tendencies, combining a measure of free individual choice with a consciousness of the inherited traditions and values of communal life" (p121). Studies into perceptions of national identity are closely associated with studies of the culture of a nation (Anderson 1991). In 1995 Kale argued that "while economic, political, and legal changes needed to homogenize Europe are daunting, the cultural heterogeneity among member nations will continue to remain the most significant barrier to integration", concluding that culture is one of the most important factors influencing buyer behaviours. Since then the accession nations have added new cultural dimensions to an already very diversified European Union. We have therefore chosen to examine identity from a cultural perspective, rather than focusing an all of the other perspectives identified by Mayer and Palmowski (2004).

\section{National identity and culture}

Laitin's (2002) conclusion from his study is that in such "dynamic national projects (as Europe has become), there is greater interest in promoting a national culture in the periphery than in the centre". We could therefore assume that there would be a great interest in the promotion of national culture within the newly acceded member states of the EU from former Eastern Bloc countries that are on the periphery of the EU and therefore further away from the continental norm. Moreover, there are also problems with defining a nation and its national and cultural identity. Studies into such issues are to be found across a range of 
academic disciplines including marketing, tourism, sociology, anthropology, and comparative management, all offering various perspectives on culture and nationhood.

Many authors believe that a national identity is conferred by where a person is born and where a person lives. However, other cultural issues are also very important contributors to a person's feeling of national identity. Kubacki and Skinner (2006) have undertaken a detailed review of these perspectives within the extant literature, summarising the elements that are perceived by various authors as being the determinants of national identity (Figure 1), and those elements assumed to communicate this identity through the national brand (Figure 2).

These symbols, or "identity markers can be defined as those characteristics which are perceived to carry symbolic importance either as a signal to others of a person's national identity, or which might be mobilised by the individual themselves in support of an identity claim" (Bechhofer et al. 1999:527-528).

Nevertheless, national identity is not a fixed construct. Although it may be slow to change, a nation's identity can and does change over time (Bechhofer et al. 1999; Cameron 1999). However, much as this identity may change and be perceived as changed by those within the nation, it is at least equally slow to be perceived as changed by those outside of the nation (Leonard 1997). Cameron (1999) asks whether "national identity [is] something of which we ourselves are aware or is it an identity which others bestow upon us?" Mayer and Palmowski (2004:577) believe that identities are constructed and accepted both from within and from outside of the nation, but that external recognition "at its most extreme it is a crucial determining factor in the creation of identities". Hogg, Cox and Keeling (2000) have also identified the importance of self-concept in purchase behaviour, stressing "the number and centrality of different views of the self which operate within the self-concept". Indeed Foxall (1994) believes that selfconcept is probably the most applicable of all the personality concepts that can be applied to marketing.

The issue of self-concept of individual consumers may also be linked to the selfconcept of individual citizens within the country. There have been a number of more recent cases following the break up of the USSR, where academics have researched the formation (or recreation) of new identities for nations that have been formed from the former Yugoslavia, namely Croatia (Hall 2002; Martinovic 2002), Montenegro (Hall 2002), Serbia (Hall 2002), Bosnia and Hercegovina (Vincent 1999) and Slovenia (Hall 2002; Konecnik 2004), and also studies into the branding of nations such as Latvia (Endzina/Luneva 2004; Dzenovska 2005). 
Figure 1. Determinants of National Identity

\begin{tabular}{|c|c|}
\hline Author & Determinants of national identity \\
\hline Herder (in Ergang, 1931) & Language \\
& Culture \\
& Political identity \\
\hline Cobban (1969) & Inherited traditions \\
& Values of communal life \\
\hline Anderson (1991) & Language \\
\hline Earley and Singh (1995) & Economic systems \\
& Legal systems \\
& Cultural systems \\
& Political systems \\
\hline Cameron (1999) & Cultural symbols \\
& Passport \\
& Residence \\
& Language \\
\hline Williams (1999) & Cultural symbols \\
& Language \\
\hline Mair and Zielonka (2002) & Political culture \\
& Language \\
& Religious beliefs \\
& Popular culture \\
\hline Fuchs and Klingemann (2002) & Clearly defined territory \\
\hline Laitin (2002) & Language \\
& Religion \\
& Popular "shallow" culture \\
& "Deep" culture \\
\hline
\end{tabular}

In addition, studies have also been undertaken into the way other nations, such as Ireland have refashioned their identities as their "reality has dramatically changed" (Olins 2002), with similar issues facing Spain (Gilmore 2002; Olins 2002). Furthermore, studies have also been undertaken on the brand identities of nations such as America (Anholt/Hildreth 2005; Johansson 2005); Armenia (Pant 2005); New Zealand (Morgan et al. 2002; Lodge 2002); Nigeria (Viosca et al. 2004); Poland (Florek 2005; Kubacki/Skinner 2006); Singapore (Haley/Low 1998); Taiwan (Amine/Chao 2005) and Wales (Pride 2002; Skinner/Croft 2004). 
Figure 2. Communicators of National Brand

\begin{tabular}{|c|c|}
\hline Author & Communicators of National Brand \\
\hline Kotler and Gertner (2002) & Geography \\
History \\
Proclamations \\
Entertainment industry \\
Media \\
Art \\
Music \\
& Famous citizens \\
& Other features \\
\hline Anholt (2002) & Culture \\
& Language \\
& Images of popular culture \\
Creative arts \\
Tourism and travel writing \\
Commercial branded products
\end{tabular}

\section{European identity}

"It has been suggested that while societies are steadily moving together that the similarities between cultures will become much greater than their differences" (Pugh/Hickson 2002), diluting distinctive individual national culture (Williams 1999), and contracting the role of the nation state (Steger 1998). Fuchs and Klingemann (2002) believe that "many feel the EU can attain democratic legitimacy only if a European demos with a collective identity takes shape". The authors are concerned that "in view of the cultural plurality and heterogeneity of European nation states, it is doubtful whether the constitution of a European demos with a tenable collective identity is possible at all". Authors such as Zielonka and Mair (2002:1) agree, believing that an enlarged EU "will be a much more diversified entity following its planned eastward enlargement". They cite elements such as political culture, language, religious beliefs and popular culture as revealing both similarities and differences between cultures. Laitin (2002) does not believe that such generalisations can be made across a newly enlarged EU. He believes that there are fundamental differences between nations from Central and Eastern Europe on the periphery of the European Union and nations that are closer to the "continental norm". His view was opposed by former Czech president, Václav Havel, who speaking in the European Parliament in 2000, declared that:

"Europe is one political entity... The idea that there could forever be two Europes - a democratic, stable and prosperous Europe engaged in integration and a less democratic, less stable and less prosperous Europe - is, in my opinion, totally mistaken. It resembles a belief that one half of a room could be heated and the other half kept unheated at the same time. There is only one Europe, 
despite its diversity, and any weightier occurrence anywhere in this area will have consequences and repercussions throughout the rest of the continent"

From a marketing perspective, Willis (1991) over 15 years ago argued that the European Community is not customer-oriented and "this is nowhere more clearly indicated than in the recent adoption of the slogan 'single market", that has been used often since EU Enlargement in 2004.

Burgoyne and Routh (1999:113) discuss the findings of the Eurobarometer 46 (1997) survey into perceptions of self and national identity in member states, a survey that is periodically undertaken by the European Commission. "One question asked respondents whether 'in the near future' they saw themselves in terms of their 'nationality only', as 'nationality and European', 'European and nationality' or European only'." Aggregating data in each country, across "Europe as a whole, 51 per cent saw themselves as 'European' to some extent", but "in all countries, those who felt mainly or wholly European were in the minority".

\section{Segmentation in the European Union}

There has been a changing paradigm in marketing away from the traditional "mix-management" approach towards issues of relationships and creation of customer value (O’Malley/Patterson 1989; Brownlie/Saren 1992; Gronroos 1994). Mercado, Welford and Prescott (2001) note that the traditional perspective involved identifying differences between markets, areas for product and service development, structures for local responses, and mix management strategies. This is now moving towards a new perspective of identifying common groups between markets, areas for standardisation and differentiation, structures for common practice and efficiency, and key areas for problem solving and common development.

Traditional segmentation by nation has often drawn on the work of Hofstede (1983) and Trompenaars (1993), who identified bipolar variables by which a national culture may be understood and assessed. There has since been a proposal for a new approach to demographic and geodemographic segmentation, undertaken by identifying clusters of customers who share common characteristics, but who may not necessarily live in the same country. This work, by Van der Merwe and L'Huillier (1989), proposed that "rather than look for one mass market or for consumers who fit old purchasing models, they (managers) need to identify clusters of Euro-Consumers and adjust their strategies and operations to cater to these new transnational groups". They identified the following clusters of consumers, many of which cross national borders: UK and Ireland (cluster 1); Central and Northern France, Southern Belgium, Central Germany and Luxembourg (cluster 2); Spain and Portugal (cluster 3); Southern Germany, Northern Italy, South-eastern France and Austria 
(cluster 4); South Italy and Greece (cluster 5); Northern Germany, the Netherlands, Northern Belgium, Iceland, Norway, Finland and Denmark (cluster $6)$.

However, these clusters do not take the newly acceded member states of the EU into account. Mercado, Welford and Prescott (2001) warn that "despite historical reference to the 'Eastern Bloc', Central and Eastern Europe is not a homogeneous area. The countries differ widely with regard to ethnic compositions, languages, historical identities, industrial structures and economies." Individual accession countries are often grouped together as Central European states. However, Willis (1991) argues that "the single market concept for the professional marketer is as irrelevant today as Henry Ford's philosophy of a mass market". Moreover, Kolman et al. (2003) argue that although there are significant differences in values between Western and Central Europe, significant differences are also visible between countries like the Czech Republic, Hungary, Poland and Slovakia. Lack of cross-cultural skills of Western managers in Central Europe was often identified as an important problem (Villinger 1996). Therefore the danger is that, even when attempting to identify clusters of Euro-Consumers in a newly enlarged EU, these countries will similarly be formed into a separate cluster perceived as homogeneous by international marketers.

\section{Methodology}

The European Commission's own research (Flash Eurobarometer 140) found that Poland, Hungary and the Czech Republic were "best known", and correctly identified as accession countries by citizens in other member states. Moreover, the total population of those three countries makes up $80 \%$ of the population of the initial accession nations in 2004, with 10.2 million people living in the Czech Republic, 10.1 in Hungary and 38.2 in Poland. Therefore these three former Eastern Bloc countries were chosen in which to undertake our research.

We have chosen to examine national identities of Central Europeans from a cultural perspective, therefore the questionnaire was compiled from the determinants of national identify identified in the literature and indicated in Figure 1 and communicators of national brand identified in Figure 2, in addition to the specific cultural symbols identified by Vincent (1999) in his work into national identity in the former Eastern Bloc nations of Bosnia and Hercegovina. Vincent notes that these specific elements of culture symbolise the messages that a cultural group wishes to convey about itself, thereby linking the outsider's perception of a cultural identity (as identified in Figure 1), to the self-concept of a nation (Foxall 1994).

Respondents were asked to rank the extent to which they agreed/disagreed that each determinant contributed to their feeling of national identity on a 7-point 
Likert scale. As the issue of self-concept of individual consumers may also be linked to the self-concept of individual citizens within the member-states of the European Union, the final part of the questionnaire replicated the European Commission survey into perceptions of self and national identity in member states.

The authors conducted the survey in the first months of 2005, following pretesting with a UK sample of 224 students. Data was collected using questionnaires administered to independent samples drawn from level 1, 2 and 3 undergraduate business students in the Czech Republic, Hungary and Poland. The respondents were surveyed in their countries of origin, using questionnaires translated into their national languages. The research team have various native skills in the languages used and so translated the paper from English into their respective native tongues, although back translation was not used, and also travelled to the relevant country to deliver the questionnaire in their own native tongue. Therefore, for example, a native Pole translated the paper into Polish, and personally travelled to Poland to administer the survey in Polish, with Polish respondents, on a Polish university campus.

Table 1. Respondent profiles

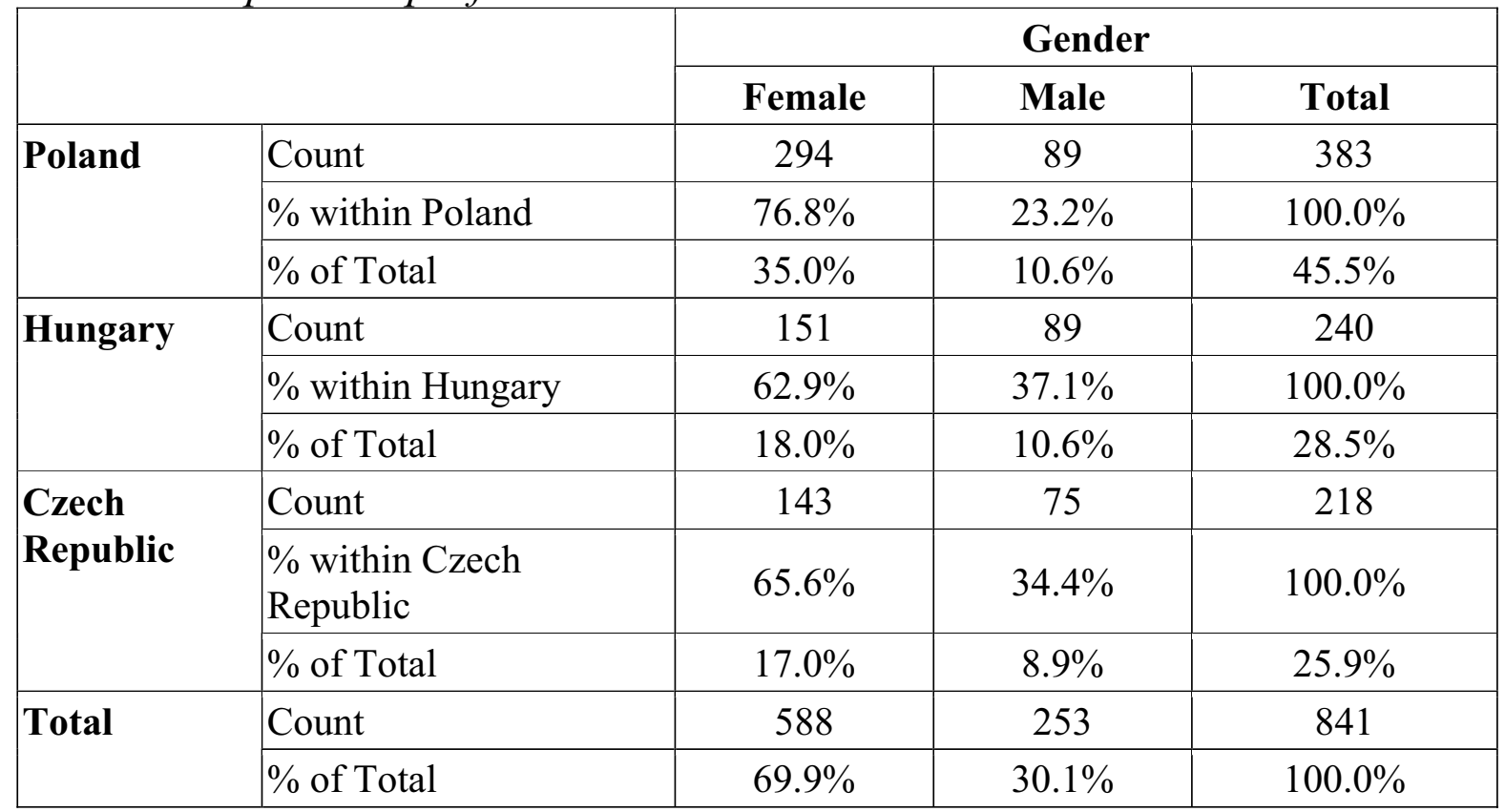




\begin{tabular}{|c|c|c|c|c|c|c|c|c|}
\hline 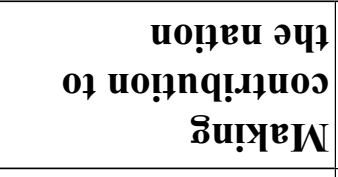 & กิ & $\underset{+}{\infty}$ & $\begin{array}{l}\infty \\
m \\
m\end{array}$ & 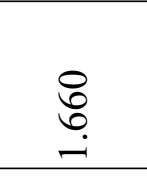 & $\begin{array}{c}\dot{\theta} \\
\dot{m}\end{array}$ & $\stackrel{\sim}{m}$ & $\begin{array}{l}\infty \\
\grave{n} \\
m\end{array}$ & $\stackrel{n}{n}$ \\
\hline 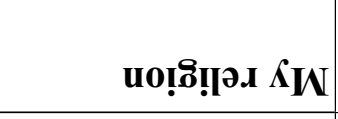 & $\begin{array}{l}\nexists \\
\dot{i}\end{array}$ & $\begin{array}{l}\infty \\
\infty \\
n \\
\end{array}$ & $\begin{array}{l}\infty \\
\infty \\
\dot{+} \\
\end{array}$ & $\stackrel{尺}{\stackrel{2}{2}}$ & $\vec{n}$ & $\begin{array}{l}\text { N} \\
\infty \\
\end{array}$ & $\begin{array}{l}\infty \\
0 \\
\dot{n} \\
\end{array}$ & $\begin{array}{l}\tilde{n} \\
i \\
i\end{array}$ \\
\hline 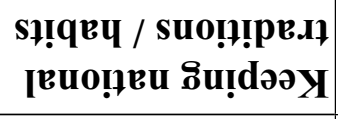 & $\underset{\infty}{\infty}$ & $\stackrel{\circ}{\dddot{2}}$ & $\begin{array}{l}0 \\
\infty \\
i \\
\end{array}$ & $\stackrel{\circ}{\stackrel{\ominus}{\sim}}$ & $\tilde{n}$ & 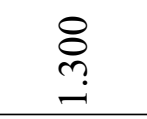 & $\vec{n}$ & $\stackrel{+}{m}$ \\
\hline 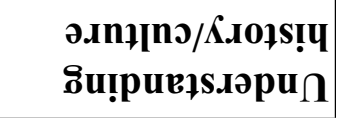 & ָั & $\Xi$ & $\frac{\infty}{\vec{v}}$ & 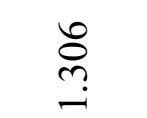 & $\frac{\dot{\Delta}}{\dot{\sim}}$ & $\stackrel{\text { \& }}{\sigma}$ & $\begin{array}{l}\infty \\
\vec{i}\end{array}$ & $\stackrel{n}{=}$ \\
\hline 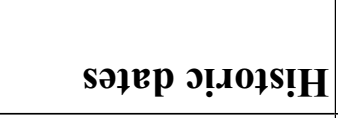 & 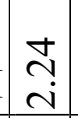 & $\begin{array}{l}\infty \\
\stackrel{\infty}{-} \\
\end{array}$ & $\hat{\tilde{s}}$ & 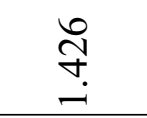 & 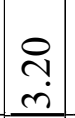 & $\stackrel{n}{m}$ & $\begin{array}{l}\hat{b} \\
\dot{i}\end{array}$ & ঙ. \\
\hline 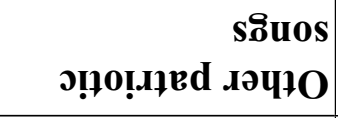 & r & $\begin{array}{l}\infty \\
\mathfrak{m} \\
\end{array}$ & $\stackrel{g}{\dot{q}}$ & $\begin{array}{l}\stackrel{0}{\circ} \\
? \\
\end{array}$ & $\begin{array}{l}\hat{O} \\
\dot{n}\end{array}$ & $\stackrel{m}{m}$ & $\begin{array}{l}0 \\
\vdots \\
\dot{n}\end{array}$ & 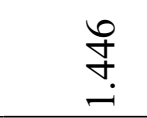 \\
\hline $\begin{array}{r}\text { шәчдив } \\
\text { [вио!ฺน әЧЈ }\end{array}$ & & $\stackrel{2}{\rightleftarrows}$ & $\begin{array}{c}n \\
n \\
\end{array}$ & $\stackrel{\infty}{\sim}$ & $\frac{n}{i}$ & $\stackrel{\infty}{\stackrel{n}{n}}$ & $\begin{array}{l}\dot{U} \\
\dot{U}\end{array}$ & ले \\
\hline 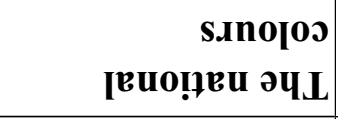 & $\bar{a}$ & $\stackrel{n}{\Xi}$ & ণ্. & $\stackrel{\infty}{\stackrel{\infty}{\rightleftharpoons}}$ & $\bar{a}$ & $\stackrel{n}{n}$ & $\begin{array}{l}\stackrel{0}{n} \\
\sim\end{array}$ & 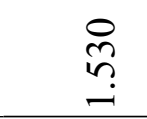 \\
\hline 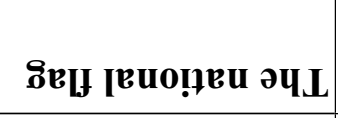 & $\stackrel{n}{\check{2}}$ & ลิ & $\underset{\sim}{\grave{n}}$ & 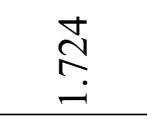 & $\begin{array}{l}0 \\
\dot{0} \\
i \\
\end{array}$ & $\frac{m}{n}$ & $\begin{array}{l}\mathscr{2} \\
\tilde{n} \\
\end{array}$ & 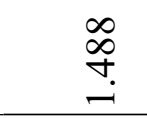 \\
\hline 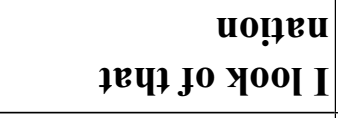 & $\stackrel{a}{\dot{\sigma}}$ & 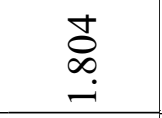 & $\begin{array}{l}n \\
0 \\
\dot{y} \\
\end{array}$ & $\frac{\hat{m}}{i}$ & $\begin{array}{c}\infty \\
n \\
n \\
m\end{array}$ & ஜ: & 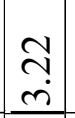 & $\begin{array}{l}\dot{t} \\
\stackrel{i}{i} \\
\text { i }\end{array}$ \\
\hline 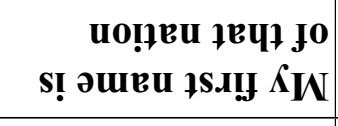 & $\frac{6}{2}$ & $\sqrt{6}$ & $\begin{array}{l}n \\
m \\
m\end{array}$ & ஓे & $\begin{array}{c}n \\
\dot{n} \\
\end{array}$ & $\stackrel{\infty}{\Omega}$ & $\begin{array}{l}m \\
i \\
\end{array}$ & $\stackrel{\substack{\infty \\
\infty}}{-}$ \\
\hline 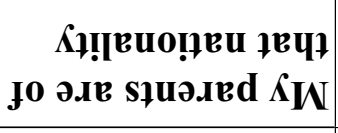 & $\tilde{n}$ & ㅇ․ & $\stackrel{n}{a}$ & $\begin{array}{l}\infty \\
\text { m }\end{array}$ & $\bar{a}$ & 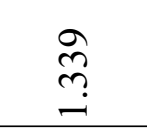 & $\underset{6}{-}$ & $\stackrel{0}{\varrho}$ \\
\hline 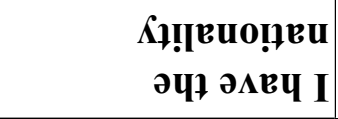 & 욤. & $\underset{\infty}{\stackrel{\Xi}{~}}$ & ڤ్ర & ลี & $\begin{array}{l}0 \\
\infty \\
-\end{array}$ & $\stackrel{a}{\stackrel{a}{-}}$ & \begin{tabular}{l}
$\infty$ \\
0 \\
\hdashline
\end{tabular} & ू \\
\hline 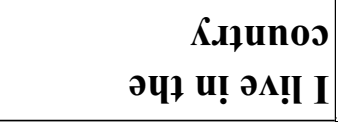 & $\stackrel{9}{2}$ & $\underset{\infty}{\infty}$ & 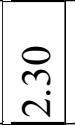 & 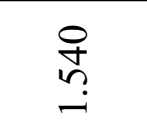 & 吕 & $\stackrel{⿱}{r}$ & 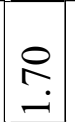 & $\stackrel{n}{\simeq}$ \\
\hline 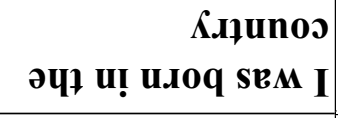 & $\stackrel{\infty}{\sim}$ & $\hat{n}$ & $\underset{n}{\sim}$ & $\underset{\text { త్ర }}{\text {. }}$ & $\stackrel{n}{\stackrel{n}{\sim}}$ & 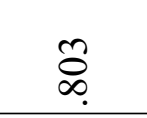 & $\stackrel{8}{8}$ & $\stackrel{\infty}{=}$ \\
\hline 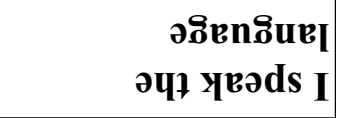 & $\stackrel{m}{+}$ & $\begin{array}{l}n \\
\infty \\
\infty\end{array}$ & $\infty$ & $\stackrel{n}{n}$ & $\underline{n}$ & $\stackrel{n}{r}$ & ñ & $\begin{array}{l}\text { Dै } \\
\text { ๙ }\end{array}$ \\
\hline 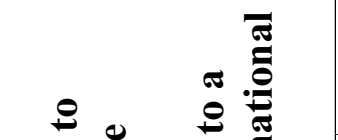 & $\sum_{\Sigma}^{\mathbb{E}}$ & 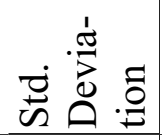 & $\sum_{\Sigma}^{\mathbb{E}}$ & 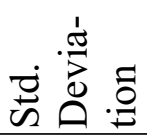 & $\sum_{\mathbb{E}}^{\mathbb{E}}$ & 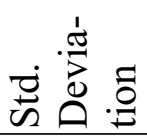 & $\sum_{\mathbb{E}}^{\mathbb{E}}$ & 总 \\
\hline 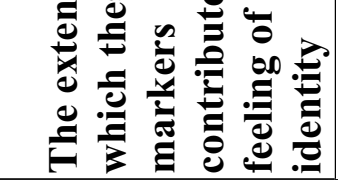 & 畩 & & : & & ¿ & & $\stackrel{\frac{\pi}{0}}{0}$ & \\
\hline
\end{tabular}




\begin{tabular}{|c|c|c|c|c|c|c|c|c|c|c|c|c|c|c|c|c|c|c|}
\hline \multirow{3}{*}{ 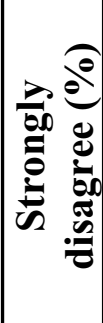 } & U & $\begin{array}{l}0 \\
\dot{\nabla}\end{array}$ & $\stackrel{0}{0}$ & 0 & 0 & $\underset{-}{\infty}$ & $n$ & $n$ & $\stackrel{\nabla}{\check{C}}$ & $\dddot{n}$ & $\stackrel{n}{0}$ & $\stackrel{n}{0}$ & 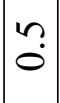 & $\stackrel{\infty}{-}$ & 0 & $\dot{0}$ & $\ddot{a}$ & $\tilde{n}$ \\
\hline & 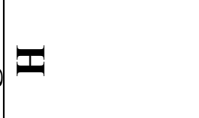 & $\stackrel{n}{\sim}$ & in & $\stackrel{\sim}{\sim}$ & \begin{tabular}{|l}
$\nabla$ \\
\end{tabular} & $\stackrel{m}{m}$ & 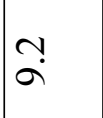 & ন & さ্ণ & $\overparen{r}$ & $\stackrel{9}{-}$ & $\stackrel{n}{\sim}$ & $\hat{6}$ & $m$ & $\stackrel{?}{n}$ & 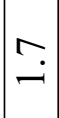 & $\left|\begin{array}{c}\infty \\
\dot{0} \\
m\end{array}\right|$ & $\begin{array}{l}\infty \\
\infty \\
\infty\end{array}$ \\
\hline & a & $\stackrel{m}{0}$ & 0 & 0 & 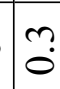 & $\stackrel{n}{0}$ & $\stackrel{\infty}{-}$ & $\stackrel{\nabla}{\dot{r}}$ & $\begin{array}{l}\infty \\
i \\
i\end{array}$ & $\stackrel{\infty}{\circ}$ & $\begin{array}{l}\infty \\
0\end{array}$ & 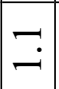 & $\overrightarrow{\mathrm{i}}$ & $\Xi$ & $\stackrel{\infty}{\circ}$ & $\Xi$ & $\vec{r}$ & $\vec{r}$ \\
\hline \multirow{3}{*}{ 를 } & U & $\because$ & 0 & 0 & $\infty$ & $\begin{array}{l}\infty \\
\stackrel{\sim}{\sim}\end{array}$ & $\begin{array}{l}\infty \\
\dot{\sim}\end{array}$ & $\stackrel{\nabla}{\underset{c}{\sim}}$ & $\underset{\Xi}{\varrho}$ & $\begin{array}{l}\sigma \\
\dot{+}\end{array}$ & $\infty$ & $\vec{m}$ & $\hat{\infty}$ & 6 & 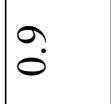 & ra & 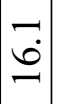 & in \\
\hline & \pm & 0 & 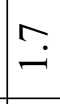 & $\stackrel{\infty}{\infty}$ & $\stackrel{\Delta}{\circ}$ & 0 & $\begin{array}{l}\infty \\
\dot{m}\end{array}$ & $\stackrel{\sim}{\forall}$ & nֶ? & $\begin{array}{l}\infty \\
\dot{m}\end{array}$ & $\exists$ & $\vec{i}$ & $\stackrel{?}{-}$ & $\stackrel{\sim}{-}$ & $\stackrel{n}{\sim}$ & $\tilde{n}$ & $\bar{r}$ & \\
\hline & a & $\stackrel{?}{0}$ & 0 & $\stackrel{n}{0}$ & 0 & 3 & $\stackrel{\nabla}{\sim}$ & $\ddot{m}$ & $\stackrel{\nabla}{\sim}$ & $\stackrel{m}{0}$ & 0 & $\stackrel{?}{0}$ & $\stackrel{?}{-}$ & $\ddot{n}$ & $\dddot{n}$ & $\tilde{o}$ & $\vec{r}$ & $\stackrel{\sim}{\forall}$ \\
\hline \multirow{3}{*}{ 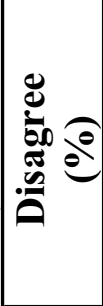 } & U & $\stackrel{?}{0}$ & 0 & 0 & F & 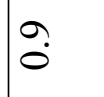 & $\stackrel{\stackrel{N}{ \pm}}{ \pm}$ & $\vec{\infty}$ & $\dot{\ddot{r}}$ & $\stackrel{m}{i}$ & $\dot{r}$ & $\stackrel{\nabla}{-}$ & 6 & $\stackrel{n}{r}$ & $\stackrel{\nabla}{\sim}$ & $\begin{array}{l}n \\
n \\
n\end{array}$ & $\stackrel{\stackrel{\sim}{\sim}}{\stackrel{\sim}{\beth}}$ & $\stackrel{n}{n}$ \\
\hline & I & 9 & $\dddot{n}$ & 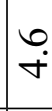 & $\stackrel{+}{\circ}$ & $\hat{\sim}$ & $\stackrel{\sim}{2}$ & 六 & $\begin{array}{l}\infty \\
i \\
i\end{array}$ & $\stackrel{+}{\circ}$ & 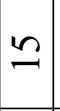 & $n$ & $\begin{array}{l}m \\
m \\
m\end{array}$ & $\widetilde{0}$ & $\vec{\sim}$ & $\stackrel{\nabla}{0}$ & $\begin{array}{l}a \\
\end{array}$ & $\stackrel{+}{\circ}$ \\
\hline & a & $\stackrel{?}{-}$ & $\dddot{m}$ & $\stackrel{n}{=}$ & 二 & $\because$ & $\hat{i}$ & in & $\stackrel{ナ}{\sim}$ & $\overrightarrow{\mathrm{i}}$ & $\vec{r}$ & $\vec{\sim}$ & 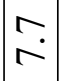 & $\begin{array}{l}0 \\
i\end{array}$ & $\stackrel{\nabla}{\dot{r}}$ & $\stackrel{\nabla}{i}$ & $\stackrel{c}{n}$ & 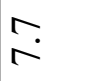 \\
\hline \multirow{3}{*}{ 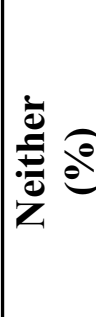 } & v & ò & 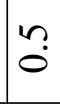 & $\infty$ & $n$ & $\begin{array}{l}0 \\
+\end{array}$ & $\stackrel{n}{n}$ & ఫิ & $\stackrel{\searrow}{\check{\beth}}$ & $\tilde{\infty}$ & $\vec{n}$ & nn & $\begin{array}{l}\sim \\
\Xi \\
\Xi\end{array}$ & $\stackrel{n}{a}$ & $\stackrel{\infty}{\sim}$ & $m$ & $\left|\begin{array}{c}n \\
\dot{v}\end{array}\right|$ & $\stackrel{n}{=}$ \\
\hline & \pm & $\approx$ & $\begin{array}{l}\infty \\
\dot{i n}\end{array}$ & in & $?$ & $\stackrel{\infty}{\infty}$ & $\stackrel{m}{\infty}$ & $\begin{array}{l}\infty \\
\ddot{\sim}\end{array}$ & $\begin{array}{l}\infty \\
\dot{\lambda}\end{array}$ & $\stackrel{n}{0}$ & $\begin{array}{l}\searrow \\
\dot{J}\end{array}$ & m. & $\begin{array}{l}0 \\
\dot{\sim} \\
\end{array}$ & $\begin{array}{l}\infty \\
\infty \\
\infty\end{array}$ & 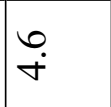 & $\begin{array}{l}\infty \\
0 \\
0\end{array}$ & $\overline{\mathrm{N}}$ & ?ֶ? \\
\hline & $\vec{a}$ & $\stackrel{\infty}{-}$ & $\stackrel{\infty}{\infty}$ & $\stackrel{n}{\sim}$ & $\stackrel{\nabla}{\sim}$ & $\stackrel{n}{=}$ & 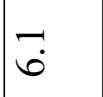 & $\begin{array}{l}0 \\
-\end{array}$ & $\begin{array}{l}0 \\
\stackrel{0}{0}\end{array}$ & $\begin{array}{l}0 \\
i\end{array}$ & $\stackrel{n}{+}$ & $\hat{\mathrm{i}}$ & $\mid \begin{array}{l}0 \\
\dot{\Xi}\end{array}$ & $\stackrel{r}{\infty}$ & $\stackrel{9}{r}$ & $\stackrel{\sim}{n}$ & $\tilde{a}$ & $\stackrel{\sim}{\sim}$ \\
\hline \multirow{3}{*}{$\sum_{0}^{\infty} e^{\infty}$} & U & $\underset{+}{\sigma}$ & $\underset{+}{0}$ & 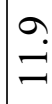 & $\stackrel{0}{a}$ & $=$ & ㄱ & 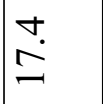 & $\stackrel{\searrow}{\check{\beth}}$ & $\begin{array}{l}0 \\
\dot{0} \\
\sim\end{array}$ & $\frac{n}{m}$ & $\begin{array}{l}\infty \\
\infty \\
-1\end{array}$ & $\begin{array}{l}0 \\
\dot{\sim} \\
\tilde{r}\end{array}$ & $\begin{array}{l}0 \\
\text { in } \\
\text { min }\end{array}$ & $\begin{array}{l}\stackrel{0}{0} \\
\stackrel{\leftrightarrow}{ }\end{array}$ & $\stackrel{?}{=}$ & $\left|\begin{array}{l}0 \\
0 \\
0\end{array}\right|$ & $\frac{N}{n}$ \\
\hline & I & 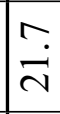 & $\overline{\mathrm{N}}$ & $\begin{array}{l}\stackrel{\sim}{\sim} \\
\text { d }\end{array}$ & $\frac{\nabla}{\sim}$ & $\hat{\tilde{N}}$ & $\stackrel{9}{I}$ & $\stackrel{\infty}{\infty}$ & $\begin{array}{l}\forall \\
\dot{v}\end{array}$ & $\bar{\sim}$ & $\frac{m}{m}$ & $\begin{array}{l}0 \\
\dot{j} \\
m\end{array}$ & $\begin{array}{l}n \\
i \\
m\end{array}$ & 芦 & $\begin{array}{l}\infty \\
i \\
i\end{array}$ & $\begin{array}{l}\infty \\
\dot{m} \\
\end{array}$ & 0 & $\ddot{\sim}$ \\
\hline & $\overrightarrow{2}$ & ले & $\dot{r}$ & $\stackrel{n}{+}$ & $\because$ & $\stackrel{\sim}{\sim}$ & $\stackrel{9}{\Omega}$ & $\hat{a}$ & $\stackrel{0}{\varrho}$ & $\begin{array}{l}\dot{\sim} \\
\ddot{\sim}\end{array}$ & $\ddot{\sim}$ & $\tilde{\sigma}^{2}$ & 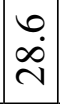 & $\begin{array}{l}0 \\
\stackrel{0}{=}\end{array}$ & $\begin{array}{l}\infty \\
\infty \\
\infty\end{array}$ & $\overrightarrow{\mathrm{i}}$ & o. & $\begin{array}{l}\forall \\
\stackrel{\leftrightarrow}{0}\end{array}$ \\
\hline \multirow{3}{*}{ 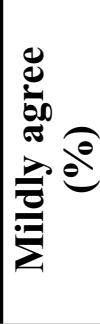 } & $\mathcal{v}$ & $m$ & ৯े & 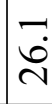 & 党 & $\vec{\AA}$ & $\frac{9}{1}$ & $\begin{array}{l}0 \\
\dot{\sim}\end{array}$ & $\stackrel{\sim}{\sim}$ & $\frac{r}{m}$ & $\begin{array}{l}0 \\
\dot{b} \\
\sim\end{array}$ & $\begin{array}{l}\hat{m} \\
\text { m}\end{array}$ & $\begin{array}{l}\searrow \\
\grave{\lambda}\end{array}$ & $\begin{array}{l}0 \\
\dot{0} \\
\sim\end{array}$ & $\stackrel{\stackrel{\sim}{\sim}}{\stackrel{f}{r}}$ & $\begin{array}{l}n \\
\dot{f}\end{array}$ & $\stackrel{\sim}{ \pm}$ & $\begin{array}{l}\infty \\
\stackrel{\sim}{\sim}\end{array}$ \\
\hline & I & $\because$ & $\begin{array}{l}0 \\
\dot{ \pm}\end{array}$ & $\begin{array}{l}\infty \\
\infty \\
\infty\end{array}$ & $\stackrel{\sim}{\simeq}$ & $\begin{array}{l}m \\
\tilde{m}\end{array}$ & ?ִ & $\hat{0}$ & $\begin{array}{l}\infty \\
\dot{n}\end{array}$ & 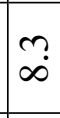 & $\begin{array}{l}\infty \\
\infty \\
\infty\end{array} \mid$ & $\begin{array}{l}\infty \\
\dot{\rho}\end{array}$ & $\begin{array}{l}\infty \\
0 \\
0\end{array}$ & $\begin{array}{l}n \\
\tilde{N}\end{array}$ & 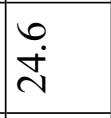 & $\stackrel{\vec{\lambda}}{\sim}$ & $\stackrel{n}{=}$ & $\begin{array}{l}\infty \\
\ddot{l}\end{array}$ \\
\hline & 2 & $\stackrel{\infty}{\dot{\lambda}}$ & $\begin{array}{l}0 \\
\end{array}$ & $\hat{\sigma}$ & $\underset{\infty}{\infty}$ & $\stackrel{\nabla}{\partial}$ & 이 & $\begin{array}{l}0 \\
\stackrel{1}{-}\end{array}$ & 艺 & $\begin{array}{l}\infty \\
\\
\dot{v}\end{array}$ & n̊?. & $\tilde{e}$ & $\begin{array}{l}\sim \\
\stackrel{0}{ } \\
\sim\end{array}$ & $\vec{\curvearrowright}$ & $\frac{0}{\infty}$ & $\frac{a}{m}$ & 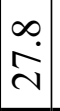 & $\frac{0}{\grave{N}}$ \\
\hline \multirow{4}{*}{ 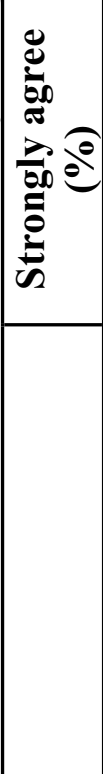 } & $\mathbf{v}$ & $\ddot{8}$ & சु & $\ddot{8}$ & $\hat{n}$ & $\frac{\infty}{\dot{n}}$ & 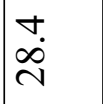 & $\begin{array}{l}a \\
\infty \\
\sim\end{array}$ & $\underset{\Xi}{ \pm}$ & ri & $\vec{n}$ & $\begin{array}{l}1 \\
0 \\
n\end{array}$ & $\vec{\infty}$ & $\stackrel{\nabla}{\circ}$ & $\stackrel{\sim}{a}$ & $\begin{array}{l}m \\
\infty\end{array}$ & $\vec{\nabla}$ & 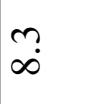 \\
\hline & I & $\frac{9}{i n}$ & $\underset{\infty}{\infty}$ & 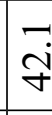 & 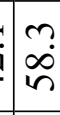 & i̊ & $\begin{array}{l}\vec{r} \\
\ddot{m}\end{array}$ & $\begin{array}{l}m \\
\infty \\
\sim \\
\sim\end{array}$ & $\begin{array}{l}n \\
\tilde{N}\end{array}$ & $\ddot{\sim}$ & $\stackrel{n}{\sim}$ & $\begin{array}{l}\vec{r} \\
\vec{n} \\
m\end{array}$ & $\begin{array}{l}\infty \\
0 \\
0\end{array}$ & $\ddot{0}$ & à & $\stackrel{\sim}{a}$ & $\stackrel{?}{-}$ & $\stackrel{\infty}{0}$ \\
\hline & a & $\stackrel{0}{\circ}$ & $\stackrel{2}{\AA}$ & $\stackrel{a}{N}$ & $\stackrel{r}{r}$ & 咅 & $\begin{array}{l}a \\
\infty \\
i n\end{array}$ & $\begin{array}{l}n \\
n \\
n\end{array}$ & $\underset{f}{\stackrel{f}{f}}$ & $i n$ & $\frac{\vec{f}}{f}$ & 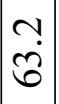 & $\begin{array}{l}0 \\
9 \\
=\end{array}$ & in & $\bar{m}$ & $\begin{array}{l}\infty \\
\dot{\infty} \\
\stackrel{+}{+}\end{array}$ & $\begin{array}{c}n \\
n \\
m\end{array}$ & $\stackrel{\searrow}{\stackrel{\sim}{二}}$ \\
\hline & 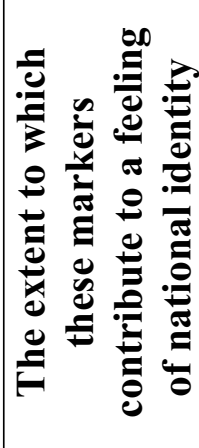 & 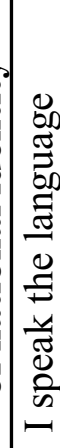 & 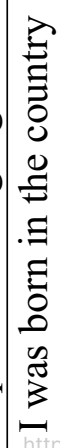 & 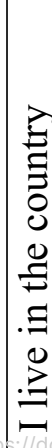 & 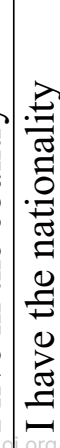 & 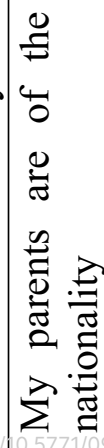 & 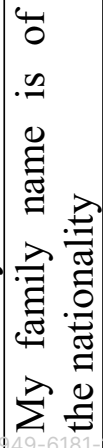 & 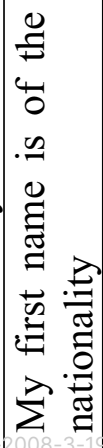 & 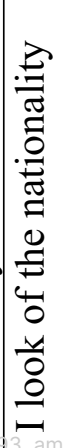 & 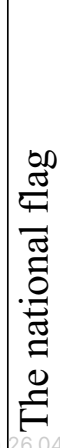 & 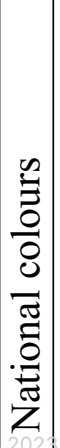 & 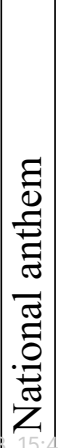 & 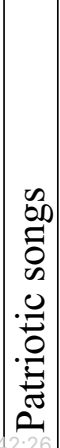 & 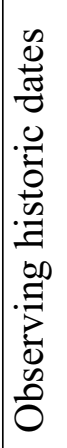 & 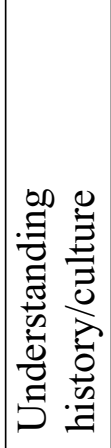 & 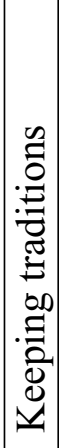 & 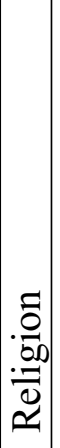 & 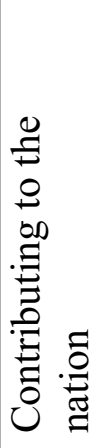 \\
\hline
\end{tabular}


The study employed the strategy of matched samples (Hofstede 1991), which "may be expected to yield accurate estimates of the differences between the countries studied", minimising potential differences between respondents, other than nationality (Kolman et al. 2003). Using university students as participants is a popular sampling method in cross-country and cross-cultural studies because of their reported superiority to random samples for establishing equivalence (Dant/Barnes 1988).

They were also characterised in earlier studies as a homogenous group easily accessible to the researcher (Calder et al. 1981). Moreover, the use of a student sample, while not representative of the population, would research the views of people in these nations who are both educated and young, reflecting core target segments for many international marketers, at a time when, according to Bechhofer et al. (1999:516) the search for a national identity in postmodern society "has become fashionable because people are not sure who they are".

841 usable questionnaires were returned. The sample consisted of 383 respondents from Poland (45.5\%), 240 from Hungary (28.5\%) and 218 from the Czech Republic (26\%). The demographic profile of the respondents is found in Table 1. Overall there was an unequal gender distribution with more female $(69.9 \%)$ than male respondents $(30.1 \%)$ in the sample; however, the gender distribution in each national sample was similar. 2 out of the 3 countries reported an average age of 21 years, with Hungary showing a relatively younger sample averaging 20 years of age. Only respondents who classified themselves as nationals of the nation in question were included in the study. All respondents were young people aged between 18 and 24, studying business subjects at degree level. This data was subjected to a frequency analysis in SPSS. The respondents' profiles, means and standard deviations for the total sample as well as the three national subsamples are presented in Tables 1 and 2:

\section{Findings}

Survey results are presented in Table 2. By using a 7-point scale clustering around the mid-point did not occur.

Table 4. Perceptions of future identity

\begin{tabular}{|l|c|c|c|}
\hline & Poland & Hungary & Czech Rep. \\
\hline Czech/Hungarian/Polish only & $11.1 \%$ & $9.6 \%$ & $12.6 \%$ \\
\hline Czech/Hungarian/Polish first, then European & $80 \%$ & $66.7 \%$ & $81.9 \%$ \\
\hline European first, then Czech/Hungarian/Polish & $7.6 \%$ & $20.8 \%$ & $4.2 \%$ \\
\hline European only & $1.3 \%$ & $2.9 \%$ & $1.4 \%$ \\
\hline
\end{tabular}

Given the accession of the Czech Republic, Hungary and Poland to the European Union in May 2004, survey respondents were also asked whether, in 
the near future, they believed they would see themselves as primarily Czech/Hungarian/Polish or European (Table 3).

\section{Discussion}

Earlier studies have identified a range of indicators of national and cultural identity. Kubacki and Skinner (2006) suggested that certain elements may contribute more than others. The findings from our survey have indicated that although individual accession countries are often grouped together as Central European states, many differences between them exist in terms of their national and cultural identities.

Both Anderson (1991) and Williams (1999) believe than language is a key indicator of such identity. However one does not become Czech, Hungarian or Polish simply by speaking the language, thereby being "invited in to the imagined community" as posited by Anderson (1991), although this was agreed to some extent as contributing to their feelings of national identity by $97.7 \%$ of our survey respondents in the Czech Republic, 96.3\% in Poland, and 94.6\% in Hungary. Furthermore, a very strong feeling of national identity is to be gained from being born in Poland (99\% of respondents) and the Czech Republic (98.7\%); however although this factor is still very significant for Hungarians, slightly less respondents agreed with it $(85 \%)$. This is a particularly interesting finding for historical reasons. Hungary is cited by Cobban (1969) as one of the nations who historically favoured definitions of nationhood based on political unity irrespective of nationality. It is therefore surprising to find that domicile is now seen to contribute less to a feeling of national identity by Hungarians than any of the other nations surveyed.

Similar responses were obtained on the questions relating to having Czech/Hungarian/Polish parents $(89.9 \%, 92.9 \%$ and $97.6 \%$ respectively), holding Czech/Hungarian/Polish nationality (89\%, 92.5\% and 96.4\%). Living in the country of origin contributes to national identity for $98.1 \%$ of Czechs, $97.1 \%$ Poles and $85.5 \%$ of Hungarians.

Vincent's (1999) study into national identity identified a number of specific cultural symbols and traditions. The national flag was agreed to contribute to a feeling of Polishness by $94.2 \%$ of survey respondents, but only $62.5 \%$ of respondents in Hungary identified it as an important element of their national feelings. Amongst Czech respondents $84 \%$ indicated the national flag influences their national feelings. A very similar tendency can be noticed in terms of the national anthem, keeping national traditions and habits, and the national colours - with the highest proportion of Poles (93\%, 92.8\% and 91.1\% respectively) identifying those elements as contributing to their national feeling, the lowest proportion of Hungarians $(83.8 \%, 74.7 \%$ and $61.4 \%$ ), and Czech respondents falling between those two groups $(88.9 \%, 82.1 \%$ and $72.9 \%)$. Understanding 
national history and culture was agreed as a contributing factor by $87.4 \%$ of Polish respondents, also $89.9 \%$ of Hungarian and $95 \%$ of Czech respondents agreed to that. Therefore although the differences between respondents on that element are not as great as those on the other national symbols, an overwhelming proportion of respondents in all three countries agreed that understanding national history and culture contributes to their national feelings.

The analysis of these cultural symbols clearly indicates that Polish respondents are the most attached to them amongst those three countries under investigation. All but one symbol (understanding national history and culture) was agreed to contribute to Polishness by more than $90 \%$ of respondents. The CBOS (2004) report published a month after the EU enlargement indicated that over $50 \%$ of respondents in the Czech Republic, Hungary and Poland believed that the most important thing that their countries can offer the enlarged EU was a 'cheap labour force'. Nevertheless, 33\% of Polish respondents pointed to tradition, moral values and religion as the significant Polish contribution (in comparison to $7 \%$ of Czechs and $13 \%$ of Hungarians) (ibid.). Those findings suggest that some cultural elements have different significance in the national identities of researched countries. Although the Polish constitution favours the definition of nation based upon political unity - "We, the Polish nations, all the citizens of the republic of Poland" - Michnik's (2003) question "Is Poland a country defined by ethnicity or by citizenship?" was clearly answered by the respondents, who showed very strong attachment to their cultural symbols. The elements like the national flag and national colours were agreed to contribute to national identity of Hungarian respondents at the lowest level (slightly above 60\%) across all countries and symbols. Significantly different attitudes of Hungarian respondents might be explained by the fact that historically, Hungary favoured definitions of a nation based upon political unity, with no necessary reference to culture. Therefore, one could be considered part of the Hungarian nation simply by being a Hungarian citizen (regardless of where one was actually born). The stronger tendency toward cultural symbols amongst Czech and Polish respondents might be also explained by the fact that both countries over the last two centuries had to rely on their cultural identity rather than political unity because of foreign domination of the Soviet Union and the Austro-Hungarian Empire (for 300 years in case of the Czech Republic) and Austria, Prussia and Russia (for over 100 years in case of Poland). Furthermore, in Poland, from the mid seventeenth century, the national parliament was taking decisions unanimously, which according to Jankowicz (1994) increased the power of aristocracy, weakening the role of political centre in the same time. Although Hungary was also a part of a former Eastern Bloc, from the mid 1960s the country enjoyed more economic and cultural freedom under the Kadar regime than any other country in Central Europe. Hungarians also played a leading role in the Austro-Hungarian Empire, which seemed to influence their tendency toward political definitions of a nation (Cobban 1969). 
Large differences between Czech, Hungarian and Polish respondents exist in terms of observing historic national dates, national family and first names and patriotic songs. A symbol agreed as a contributor to a feeling of national identity by survey respondents in Poland was having a Polish family name $(86.8 \%)$ and Polish first name (80.8\%). The same symbols were agreed by $63.3 \%$ and $66.9 \%$ Czechs and only by $59.6 \%$ and $53.3 \%$ Hungarians respectively. Patriotic songs were agreed to contributing to national feelings by $74.4 \%$ of survey respondents in Poland and by $70.7 \%$ in the Czech Republic. Notably that symbol contributes to a feeling of national identity for fewer respondents in Hungary $(54.1 \%)$. National dates are important contributors for $65.6 \%$ and $69.6 \%$ of Czech and Hungarian respondents respectively. However, Polish respondents perceived their role as much more important $(84.4 \%)$. Look, agreed as contributing to a feeling of Polishness by $73.9 \%$ of survey respondents, although offering a significant indicator in Vincent's (1999) work, contributed slightly less to national identity among Czechs (54.6\%) and Hungarian respondents (only $33.7 \%$ ). Those differences might be partially explained by the fact that Polish culture is the most collectivist amongst those three, while Czech culture shows the strongest tendency towards individualism (Kolman et al. 2003). The belief in a common set of national symbols might be correlated with the feeling of collective (national) identity. Making a contribution to the country was agreed as a contributor by $70.3 \%$ of survey respondents in the Czech Republic, but only by $49.9 \%$ of respondents in Hungary, with Poles falling between those two groups $(60.4 \%)$. The negative attitude towards that factor might be explained by the years of communist ethic of 'voluntarily work for a country' (the Soviet 'urawnilowka') and shared responsibility (see for example Nasierowski/Mikuła 1998). The most significant difference amongst all of the determinants and communicators of national identity was indicated on religion. The answer to Michnik's (2003) question "Who defined the new Poland? Was it the 'Catholic Pole', ethnically and religiously defined?" is positive for $79.9 \%$ of Polish respondents. This cannot be a surprise due to the role that the Catholic Church has had in Polish culture for centuries. However, religion plays a role in national identity for only $22.6 \%$ of Hungarians and $29.4 \%$ of Czechs, which can be explained by the fact that most Czechs and Hungarians are not particularly religious. Moreover, Communist regimes in those countries successfully suppressed any religious tendencies in those nations.

Laitin (2002) believes that the Central and Eastern European nations differ greatly from those in Western Europe. He also believes these peripheral nations are more interested in promoting national culture than those closer to the central "continental norm" of the EU. Survey respondents in Central Europe believed that, in the near future, only $9.6 \%, 11.1 \%$ and $12.6 \%$ would see themselves as Hungarian, Polish or Czech (respectively) only, yet $81.9 \%$ and $80 \%$ of respondents in the Czech Republic and Poland respectively believe they would see themselves as Czech or Polish first, then European. A slightly stronger 
tendency towards European identity is revealed by Hungarians respondents, as $66.7 \%$ believe they would see themselves as Hungarians first, then Europeans in the near future. As the question in the survey asked about the 'near future', it might have been understood in slightly different ways in the researched countries. Kolman et al. (2003) suggests the strongest long-term orientation amongst Hungarians. The much faster economic improvements in Hungary than in the other Central European countries (ibid.) and tendency towards long-term goals might positively affect their attitudes towards European identity. Moreover, Hungary was also identified by Manrai et al. (2001) as the most Westernized of all the Central and Eastern Europe nations, and the most developed of these nations "in terms of economic as well as market development. In fact, Hungary is one of the highest ranking countries in the whole of Central and Eastern Europe" (273).

As the new EU countries are likely to notice the positive influence of the enlargement on their life only in longer timescale, respondents in Poland and the Czech Republic might prefer short-terms profits, hardly visible over the first few years of EU membership. Nevertheless this is evidence of further change for the Czech Republic, Hungary and Poland, and one that will bring about more challenges for these nations' futures as full members of the European Union.

\section{Conclusions}

Last year's further enlargement of the European Union created a domestic European market of almost half a billion consumers in 27 member states. Increasing interests among researchers led them to investigate various challenges of integrating such a diverse, not only politically and economically, but above all culturally, group of nations, including now 10 member states from the former Eastern Bloc. Several of authors argued that in a European context globalisation will lead to cultural similarities overshadowing cultural differences (Pugh/Hickson 2002; Zielonka/Mair 2002). However, although research presented in this paper confirms that there is a high degree of similarity between the researched nations, they do not easily form one Central or Eastern European "cluster of affinity" within an enlarged EU, therefore companies entering the region should not always assume it is "culturally and economically undifferentiated" (Rojsek 2002:509). Although transnational groups of EuroConsumers proposed by Van der Merwe and L'Huillier (1989) do not take the newly acceded member states of the EU into account, there is a risk that because of political and economic parallels international marketers will group the Czech Republic, Hungary and Poland together, ignoring cultural differences between them. In the light of Kale's (1995) belief that culture is one of the most important factors influencing buyer behaviours, those countries might not be homogeneous enough to create a coherent segment. As all the data in this research was collected from students, it therefore might be beneficial in the 
future to also consider the views and perceptions of respondents representing more diversified parts of the studies nations, making the sample more representative for the whole population.

Our findings indicate that homogeneous Central European identity appears to be a generalisation imposed on those countries by recent history. Despite many similarities, very strong differences exist between the Czech Republic, Hungary and Poland in terms of their national and cultural identities. Morgan, Pritchard and Pride (2002) found that some nations have underdeveloped identities, and that is definitely the case with the Czech Republic, Hungary and Poland, nations that are often grouped together as "Central European, post-communist, developing, new EU countries". Our study indicates that there are large cultural differences between those countries that have to be taken into account by policymakers as well as international marketers. The findings suggest that some cultural elements have different significance in their national identities. At a time when a single European identity is attracting increasing attention from politicians and policy-makers as well as marketers, a better understanding of cultural differences between EU member states may help them in developing better-informed policies and regulations, or simply better-suited segmentation strategies taking into account not only cultural similarities between consumers, but also some important cultural differences amongst them. This approach may therefore be seen to encourage cultural uniqueness and diversity among member states, not forcing them into a single European identity.

In terms of managerial recommendations, the varying perceptions of importance of national symbols (like national flags, colours, anthems and traditions) and cultural traditions (historic national dates, national family and first name and patriotic songs, religion, look and contribution to country) in national and cultural identities in those countries cannot be neglected by international marketers when grouping them together into one segment, even if, in order to maintain economies of scale, only minor adaptations are made to the product/service offering that take these cultural differences into account. These changes could be as simple, but as effective, as changing the music on a commercial (Liszt for Hungary, Chopin for Poland, Dvorak for the Czech Republic) making your product adapted in the eyes of local consumers. Further research and consultations should also be conducted with managers and marketers working for companies operating in Central and Eastern European countries, providing other perspectives on the issues of national identities. Kolman et al. (2003) argues that "it would from a managerial perspective be dangerous to treat the Central European countries as a homogeneous group", even if the temptation is very strong because of the differences between Western and Central European countries. 


\section{References}

Amine, L.S./Chao, M.C.H. (2005): Managing country image to long-term advantage: The case of Taiwan and Acer, in: Place Branding, 1, 2, 187-204.

Anderson, B. (1991): Imagined communities: reflections on the origin and spread of nationalism, Revised edition. London and New York: Verso.

Aveline, J. (2006): Branding Europe? Branding, design and postnational loyalties, in: Place Branding and Public Diplomacy, 2, 4, 334-340.

Anholt, S. (2002): Foreword, in: Journal of Brand Management, 9, 4/5, 229-239.

Anholt, S./Hildreth, J. (2005): Let freedom and cash registers ring: America as a brand, in: Place Branding, 1, 2, 164-172.

Bechhofer, F./McCrone, D./Kiely, R./Stewart, R. (1999): Constructing national identity: arts and landed elites in Scotland, in: The Journal of the British Sociological Association, $33,3,515-534$.

Bean, C.J./Robinson Jr., L. (2002): Marketing's role in the knowledge economy, in: Journal of Business and Industrial Marketing, 17, 2/3, 204-214.

Brownlie, D./Saren, M. (1992): The four Ps of the marketing concept: prescriptive, polemical, permanent and problematical, in: European Journal of Marketing, 26, 4, 34-47.

Burgoyne, C.B./Routh, D.A. (1999): National identity, European identity and the Euro, in: Cameron K. (ed.): National Identity, Exeter: Intellect Books.

Calder, B.J./Phillips, L.W./Tybout, A.M. (1981): Designing research for applications, Journal of Consumer Research, 8, 2, 197-207.

Cameron, K. (ed.) (1999): National Identity, Exeter: Intellect Books.

CBOS (2004): Co Polska, Czechy, Słowacja i Węgry mają do zaoferowaniaUnii Europejskiej, Warszawa, June, www.cbos.com.pl.

Cobban, A. (1969): The nation state and self-determination, London: Fontana.

Dzenovska, D. (2005): Remaking the nation of Latvia: anthropological perspectives on nation branding, in: Place Branding, 1, 2, 173-186.

Earley, P.C./Singh, H. (1995): International and intercultural management research: what's next?, in: Academy of Management Journal, 38, 2. 327-340.

Endzina, I./Luneva, L. (2004): Development of a national branding strategy: the case of Latvia, in: Place Branding, 1, 1, 94-105.

Ergang, R.R. (1931): Herder and the Foundations of German Nationalism, New York: Octagon Books.

Flash Eurobarometer 140 (2003): Enlargement of the European Union, 11/04/2003.

Florek, M. (2005): The country brand as a new challenge for Poland, in: Place Branding, 1, 2, 205-214.

Foxall, G.R./Goldsmith R.E. (1994): Consumer psychology for marketing, London: Routledge. 
Fuchs, D./Klingemann, H-D. (2002): Eastward enlargement of the European Union and the identity of Europe, in: Mair, P./Zielonka, J. (eds): The enlarged European Union: diversity and adaptation, London: Frank Cass publishers.

Gellner, E. (1983): Nations and Nationalism, Ithaca: Cornell University Press.

Gilmore, F. (2002): A country - can it be repositioned? Spain - the success story of country branding, in: Journal of Brand Management, 9, 4/5, 281-293.

Gronroos, C. (1994): From marketing mix to relationship marketing: towards a paradigm shift in marketing, in: Management Decision, 32, 2, 17-18.

Haley, U.C.V./Low, L. (1998): Crafted culture: governmental sculpting of modern Singapore and effects on business environments, in: Journal of Organizational Change Management, 11, 6, 530-553.

Hall, D. (2002): Brand development, tourism and national identity: the re-imaging of former Yugoslavia, in: Journal of Brand Management, 9, 4/5, 323-334.

Havel, V. (2000): Address before the Members of the European Parliament, Strasbourg, France, 16 February, http://old.hrad.cz/president/Havel/speeches/2000/1602_uk.html.

Hofstede, G. (1981): Cultures and organization: software of the mind, London: McGraw-Hill.

Hofstede, G. (1983): National cultures in four dimensions: a research theory of cultural differences among nations, in: International Studies of Management and Organizations, 13, 1/2, 46-74.

Hogg, M.K./Cox, A./Keeling, K. (2000): The impact of self-monitoring on image congruence and product/brand evaluation, in: European Journal of Marketing, 34, 5/6, 641-665.

Holden, N. (2004): Why marketers need a new concept of culture for the global knowledge economy, in: International Marketing Review, 21, 6, 563-572.

Jankowicz, A.D. (1994): The new journey to Jerusalem: mission and meaning in the managerial crusade to Eastern Europe, in: Organization Studies, 15, 4, 479-507.

Johansson, J.K. (2005): The new brand America, in: Place Branding, 1, 2, 155-163.

Jonscher, C./Summerfield, A. (1994): Prospects for Western food companies in Central and Eastern Europe, in: British Food Journal, 96, 1, 4-9.

Kale, S.H. (1995): Grouping Euroconsumers: a culture-based clustering approach, in: Journal of International Marketing, 3, 3, 35-48.

Konecnik, M. (2004): Evaluating Slovenia's image as a tourism destination: a self-analysis process towards building a destination brand, in: Journal of Brand Management, 11, 4, 307-316.

Kotler, P./Gertner, D. (2002): Country as brand, products, and beyond: a place marketing and brand management perspective, in: Journal of Brand Management, 9, 4/5, 249-261.

Kubacki, K./Skinner, H. (2006): Poland: exploring the relationship between national brand and national culture, in: Journal of Brand Management, 13, 4, 284-299.

Kolman, L./Noorderhaven, N.G./Hofstede, G./Dienes, E. (2003): Cross-cultural differences in Central Europe, in: Journal of Managerial Psychology, 18, 1, 76-88. 
Laitin, D. (2002): Culture and national identity: 'The East' and European integration, in: Mair, P./Zielonka, J. (eds): The enlarged European Union: diversity and adaptation, London: Frank Cass publishers.

Lodge, C. (2002): Success and failure: the brand stories of two countries, in: Journal of Brand Management, 9, 4/5, 372-384.

Manrai, L.A./Lascu, D-N./Manrai, A.K./Babb, H.W. (2001): A cross-cultural comparison of style in Eastern European emerging markets, in: International Marketing Review, 18, 3, 270-285.

Martinovic, S. (2002): Branding Hrvatska - a mixed blessing that might succeed: the advantage if being unrecognisable, in: Journal of Brand Management, 9, 4/5, 315-322.

McRobbie, A. (1994): Postmodernism and popular pulture, London: Routledge.

Michnik, A. (2003): What Europe means for Poland, in: Journal of Democracy, 14, 4, 128136.

Mayer, F.C./Palmowski, J. (2004): European identities and the EU - the ties that bind the peoples of Europe, in: Journal of Common Market Studies, 42, 3, 573-559.

Mercado, S./Welford, R./Prescott, K. (2001): European Business ( $4^{\text {th }}$ Ed), Harlow, England: Pearson Education.

Morgan, N./Pritchard, A./Piggott, R. (2002): New Zealand. 100\% pure. The creation of a powerful niche destination brand, in: Journal of Brand Management, 9, 4/5, 335-354.

Nasierowski, W./Mikuła, B (1998): Culture dimensions of Polish managers: Hofstede's indices, in: Organization Studies, 19, 3, 495-509.

Olins, W. (2002): Branding the nation - the historical context, in: Journal of Brand Management, 9, 4/5, 241-248.

O'Malley, L./Patterson M. (1989): Vanishing point: the mix management paradigm reviewed, in: Journal of Marketing Management, 14, 8, 829-852.

Paliwoda, S./Marinova, S. (2007): The marketing challenges within the enlarged single European market, in: European Journal of Marketing, 41, 3/4, 233-244.

Pant, D.R. (2005): A place brand strategy for the Republic of Armenia: 'Quality of context' and 'sustainability' as competitive advantage, in: Place Branding, 1, 3, 273-282.

Pride, R. (2002): Brand Wales: 'Natural revival', in: Morgan, N./Pritchard, A./Pride, R. (eds.): Destination Branding: creating the unique destination proposition, Oxford: Butterworth-Heinemann.

Pugh, D.S./Hickson, D.J. (2002): On organisational convergence, in: Warner, M./Joynt, P. (eds.): Managing across cultures: issues and perspectives, $2^{\text {nd }}$ Edition, London: Thomson Learning.

Rojsek, I. (2001): A comparison of the purchasing behaviour of Slovenian and other Eastern European consumers, in: International Marketing Review, 18, 5, 509-520.

Skinner, H./Croft, R. (2004): Creating the cool: exploring the concept of national branding, in: International Journal of Applied Marketing, 3, 2, 3-21.

Steger U. (ed.) (1998): Discovering the new pattern of globalization. Report of the Ladenburg Kolleg Understanding and Shaping Globalization. Ladenburg: Gottlieb Daimler und Karl Benz-Stiftung. 
Trompenaars, F. (1983): Riding the waves of culture: understanding cultural diversity in business, $2^{\text {nd }}$ edition, Nicholas Brealey.

Williams, L. (1999): National Identity and the Nation State: construction, reconstruction and contraction, in: Cameron, K. (ed.): National Identity, Exeter: Intellect Books.

Willis, G. (1991): The single market and national marketing thinking, in: European Journal of Marketing, 25, 4, 148-156.

Van der Merwe, S./L'Huillier, M.A. (1989): Euro-Consumers in 1992, in: Business Horizons, $32,1,34-40$.

Villinger, R. (1996): Post-acquisition managerial learning in Central East Europe, in: Organization Studies, 17, 2, 181-206.

Vincent, J.A. (1999): Symbols of nationalism in Bosnia and Hercegovina, in: Cameron, K. (ed.): National Identity, Exeter: Intellect Books.

Viosca Jr., R.C./Bergiel, B.J./Balsmeier, P. (2004): Effects of the electronic Nigerian money fraud on the brand equity of Nigeria and Africa, in: Management Research News, 27, 6, 11-20.

Zielonka, J./ Mair,P. (2002): Introduction: diversity and adaptation in the enlarged European Union, in: Mair, P./Zielonka J. (eds): The enlarged European Union: diversity and adaptation, London: Frank Cass publishers. 